\title{
Looking through the New World of Mathematics: Experiences of College Students in Mathematics in the Modern World Course \\ Paper ID: 100941220222828
}

\author{
Ellvan M. Campos, MSc ${ }^{\text {a }}$, Ma. Melanie N. Edig, PhD ${ }^{\text {b }}$ \\ aellvan.campos@dnsc.edu.ph \\ bmamelanie.edig@dnsc.edu.ph \\ ${ }^{a}$ Instructor, Panabo City, Davao Del Norte, 8105, Philippines \\ ${ }^{\mathrm{b}}$ Associate Professor, Panabo City, Davao Del Norte 8105, Philippines
}

\begin{abstract}
This study focuses on exploring the lived experiences of college students in Mathematics in the Modern World course. Using the phenomenological qualitative research design, struggles, coping mechanisms, and insights are asked from 11 participants of the study. Results revealed that the struggles of the college students are on class interaction and resources, and learning techniques. Also, it was found out that the coping mechanisms includes technological skills, learning management, and positive attitudes. Meanwhile, their insights focused on the application of the course to the real world. Implications and recommendations are discussed.
\end{abstract}

Keyword: College Students; Learning Experiences; Mathematics in the Modern World Course; Philippines

\section{Main text}

\subsection{Introduction}

Many academic institutions see the potential of mathematical skills in propelling students' success in their future careers, regardless of their field of focus. With the embedment of Mathematics in people's culture and day-to-day interactions (Nitisha, 2018), students may be motivated for successful dealing with the complexity of the real-life mathematical tasks and decision-making (Abramovich, Grinshpan, \& Milligan, 2019; Kusmarynono, 2014).

Despite of its established importance, Mathematics is viewed as a difficult discipline that leads to students' low performance in various mathematical tasks (Wallace, 2018; Gaffor \& Karukkan, 2015). Because of this procrastination, students will have low academic achievement in Mathematics (Ojo, 2019; Asikhia, 2010) which eventually yielded to anxiety and low self-efficacy of the students (Reyes, 2019; Hodges \& Kim, 2013).

This problem is evident in the Philippine setting based on results of various standardized tests in Mathematics. Just last December 2019, the Philippines participated on the other international assessment, the Programme for International Student Assessment (PISA) last 2018, and results revealed that the Philippines ranked 78th of 79 countries in Mathematics performance (Schleicher, 2019). Moreover, the 2016-2017 data of the 2015-2016 Global Competitiveness Report of the World Economic Forum revealed that Philippines ranked 79th of 138 countries in Mathematics and Science education (Schwab \& Sala-i-Martin, 2016). In the national level, it is found that the Mean Percentage Score (MPS) of the high school students in their National Achievement Test (NAT) in Mathematics remains to be under 50\%, as compared to other subjects (Education for All National Review Report, 2015). 
Because these students are expected to enroll for their undergraduate studies, the Commission on Higher Education (CHEd) made a way to cater the problem of students' performance in Mathematics. The CHEd designed a new general education course in Mathematics to help the students see and apply mathematical concepts in their daily lives, such as managing finances, innovating designs, understanding codes, making wise decisions, and allocating resources (CMO No. 20, s. 2013). In the first year of implementation, however, a study in Bukidnon State University revealed that majority of the students performed low in the said course [14]. Moreover, a different study in this course revealed that gender played a role in their performance of the course, as male students believed that checking solutions, enjoyment, and usefulness of Mathematics are major determinants of learning Mathematics in the Modern World while majority of the female students agree that employing multiple solutions is a major determinant of learning the course (Pagtalunan, 2019).

Because the course is just in its third year of implementation, scarce studies are available in understanding how students perform in the said course. In fact, no study has mentioned details on students' struggles, coping mechanisms, and insights in Mathematics in the Modern World course, as the only general education course in Mathematics. Therefore, there is a need to conduct a research on the lived experiences of college students who already have undergone this course.

\subsection{1. "Mathematics in the Modern World" Course}

The new curriculum of Philippine colleges and university, as mandated by the CHEd, includes more student-centered courses for the students, in line with the new education system known as the Outcomes-based Education (OBE). In this modern education system, students should be exposed to various social and natural realities where they can showcase intellectual and civic capacities in producing efficient and effective responses through independent and collective efforts (CMO No. 20, series of 2013). Since some higher education courses were brought down to the Senior High School (SHS) level by the Department of Education (DepEd), as part of the changes made in the basic education of the Philippines, higher education courses were modified as well. In Mathematics, for example, the previous general education courses were replaced by only one course, the Mathematics in the Modern World.

Mathematics in the Modern World is a course designed to focus on the relevance of Mathematics to the external environment of the students. To realize this, the CHEd constructs the syllabus of this course that will provide students the tasks to analyze financial transactions, spot patterns and other methods to solve real-world problems, understand how communication works in a more efficient and logical manner, and allocate resources through wise decision-making skills (CMO No. 20, series of 2013).

The course is divided in two sections: The Nature of Mathematics and Mathematics as a Tool. The first section, which is composed of three chapters, presents how mathematics works by understanding its relevance and its ways. The chapters under this section are Mathematics in our World, Mathematical Language and Symbols, and Problem Solving and Reasoning. On the other hand, the second section, which consists of nine chapters, focuses on the different applications of mathematics in various fields of work. The chapters under this section are Data Management, Geometric Designs, Codes, Linear Programming, Mathematics of Finance, Apportionment and Voting, Logic, Mathematics of Graphs and Mathematical Systems. However, only six or seven chapters will only be discussed in this course for the entire semester. The CHEd mandated only the three components of the first section and the Data Management component of the second section as mandatory lessons for the course. However, the CHEd left the freedom to mathematics professors in choosing only two or three lessons to be taught to the students from the remaining eight components (CMO No. 20, series of 2013).

\subsubsection{Experiential Learning Theory}

This study is anchored on the Experiential Learning Theory (ELT) by David A. Kolb, which posits that learning is cycle that involves dual dialectics of action/reflection and experience/abstraction. It is based on the prominent works of James, Dewey, Piaget, Vygotsky, Jung, and others, who emphasizes the central role of experience in various theories of human learning and development (Passarelli \& Kolb, 2012). Through these works, models that holistically illustrates the process of learning from experience and adult development were made. It is in these ideas that Kolb (Kolb, 1984) was able to propose six characteristics of experiential learning, which can be used to support the learning experiences of college students in their journey in their Mathematics courses.

First, learning is best believed as a process, and not based on outcomes (Kolb, 1984). With emphasis on critical thinking and problem-solving skills, Mathematics as a discipline centralizes on the developmegntrof these by undergoing the process of solving mathematical tasks and reflecting mathematical decisions. Second, 
learning is a re-learning (Kolb, 1984). Before students are immersed in undergraduate Mathematics courses, they already have ideas on the fundamentals of Mathematics, which are utilized to draw out new and advanced version of their mathematical knowledge. Third, learning requires solving conflicts aroused from opposing modes of adaptation to the world (Kolb, 1984). Difficulties and confusion encountered by students in Mathematics courses serve as drive in the learning process, as constant iterations of opposing modes result to sound reflection and actions. Fourth, learning is holistic (Kolb, 1984). Students' experiences in Mathematics allows them to be equipped with knowledge, skills, and attitudes, by enabling them to be critical, creative, and persistent. Fifth, learning is an interaction between a person and its environment (Kolb, 1984). Students' existing mathematical concepts partnered with new experiences and applications enable them to strengthen learning. Sixth, learning involves creating knowledge (Kolb, 1984). In As knowledge comes in two forms social and personal, experiences in a Mathematics class allows self-reflection and social interaction in order to solidify learning.

Furthermore, ELT also believed that knowledge is a product of a transformation of experience. This is divided as grasping experience, which involves how an individual acquire information, and transforming experience, which involves how individual process such information. The ELT model provides two related modes of grasping experiences - Concrete Experience (CE) and Abstract Conceptualization (AC), whereas transforming experience also have two - Reflective Observation (RO) and Active Experimentation (AE) (Kolb, 1984). This model posits that the creative tension of these four learning modes allows students' learning [16]. When broken down in simple experiences in Mathematics courses, it can be portrayed as a cycle in which students have to undergo. Learning experiences designed by the teachers (CE), self-reflection from derived understanding (RO), brainstorming and sharing of ideas (AC), and crafting and designing learning output (AE) were all essential stages of the learning process in Mathematics.

\subsection{Objectives of the Study}

Based on the characteristics of the ELT, the study identified down three aspects to be aimed in determining the lived experiences of the college students in Mathematics in the Modern World course. Specifically, this study sought to determine the struggles, coping mechanisms, and insights of the college students in the said course.

\subsection{Materials and Methods}

\subsubsection{Research Design}

The study utilized a qualitative research design to gather themes on the struggles, coping mechanisms, and insights of the college students in Mathematics in the Modern World course. As this study sought to document first-hand experiences of the students in the course, this design will elaborate analyzed discussions of the recent experiences by students themselves (Creswell, 2018). To realize this, a phenomenological approach in qualitative study was adopted to describe the experiences of the individual about the existing phenomenon (Creswell, 2018). Through this approach, the researcher will understand how individuals act and construct their worldview towards a certain phenomenon (Phillips-Pula, Strunk, \& Pickler, 2011). Thus, this study structured a series of in-depth interview from a sample of the population to obtain methodical understanding of their lived experiences in Mathematics in the Modern World course.

\subsubsection{Research Participants}

As part of the qualitative study, the participants should "experience the phenomenon being studied" (p. 118) (Creswell, 2012) for them to qualify in this study. To achieve this, a purposive convenience sampling strategy was utilized in order to select the participants who had experiences of the given phenomenon. This helped ensure that the most accurate and credible descriptions will be gathered to discuss the phenomenon.

In the study, a list of college students of the Davao Del Norte State College who passed the Mathematics in the Modern World course were secured to determine the population of the study. To narrow the population, the researcher identified the top performers, middle performers and low performers in the course from every institute for a series of in-depth interviews through phone calls. To determine the participants as top performers, middle performers and low performers, the CHEd grading system was used to measure the levelimfosstudents' performance in Mathematics in the Modern World course. This was done by asking the list of class with their 
remarks as classified by their instructors according to the three classifications mentioned in the previous statement from their respective instructors. For the IAAS and IMaGoCs, the sections referred are those of the first semester, SY 2019-2020. For the IEd and IIT, however, the sections referred were those of the second semester, SY 2018-2019, since the first-year students were still taking the course in the recent semester, SY 2019-2020, during the conduct of this study. These students were ensured to be 18 years old and above. Because some of the students were not able to respond to the messages for 2 weeks and some have problems with phone signals, the number of participants were narrowed down to $11-3$ from ITEd, 2 from IIT, 4 from IMaGoCS, and 2 from IAAS. This is a considerable figure as sample sizes for phenomenological studies vary from 5 to 30 (Smith \& Osborn, 2008).

\subsubsection{Data Gathering Procedure}

To gather relevant data from the participants, an interview guide was prepared based on the Experiential Learning Theory, to suit to the needed information of the study. Questions were stated in English, Filipino, and Visayan language to facilitate effectiveness in understanding ideas. Part of this preparation is to ensure an understandable informed consent for the participants. All the instructions, including ensuring the confidentiality of participants' identity and responses, and the voice recording to help the researchers in transcribing and translating data, are reflected in the informed consent. Afterwards, the informed consent and interview guide are submitted to the pool of experts for validation, the ethics committee for the approval, and the non-target participants for pilot testing.

To begin the data gathering procedure, the researcher asked permission from the Davao Del Norte State College Graduate School to conduct the study. Then, the researcher submitted a letter of request to conduct a survey on the study to the president of the Davao Del Norte State College. Upon the approval to conduct the study, the target participants were formally informed. The procedure began after the participants were identified. After receiving the list from the different Mathematics instructors, the researcher sent personal messages to the students through their Messenger account asking their approval for a phone call interview and their preferred schedule if ever they decide to approve their participation. Once they confirmed, they were given copies of the background of the study and were oriented on what the study is all about. An Informed Consent Form were also forwarded to them afterwards signifying their agreement to be interviewed and audio-recorded. These consents were returned back to the researcher with an affixed signature as approval. Due to the COVID19 pandemic, the researcher decided to conduct a phone call interview to safeguard the participants as they participate in this study. However, Farooq and De Villiers (Farooq \& De Villiers, 2017) ensure that telephonic qualitative research interview is still a valuable instrument in gathering data qualitatively. They have given guides to follow before, during, and after the interview which the researcher observed.

\subsubsection{Data Analysis}

In the analysis of data, all interviews from the series of in-depth interviews through phone call was recorded and transcribed verbatim, and pseudonyms was given for each interviewee for the confidentiality of their identity. The study used the phenomenological data analysis steps of Moustakas (Moustakas, 1994) which involves phenomenological reduction, imaginative variation, and construction of the essence of experience. This will allow for an in-depth understanding of the full phenomenon based on the participants' own experiences (Creswell, 2013). It began with reading the transcriptions repetitively to lift up horizons for data reduction. These horizons were the interviewees' responses related to the research questions of the study (Creswell, 2012) to determine the readiness of the college students in Mathematics in the Modern World course. Equivalent, parallel and contradictory statements pertaining to the same concept were treated as one horizon. Imaginative variation began with the construction of structural description of participants' experiences from the phenomenological reduction, and the overall description of the experience (Creswell, 2013). To determine the lived experiences of the participants in Mathematics in the Modern World, then, thematic analysis was used. This method is applied to a set of texts, which closely examines the data to identify common themes - topics, ideas and patterns of meaning that come up repeatedly (Creswell, 2013), thereby constructing meaning of the studied phenomenon. 


\subsubsection{Participants Background Information}

There are 11 participants of the study -5 are male and 6 are female, as shown in Table 1 . All of them passed the Mathematics in the Modern World course. Five of them were categorized as top performing, 4 as middle performers, and 2 are low performers.

Table 1. Demographic Profile of the Participants

\begin{tabular}{cccc}
\hline $\begin{array}{c}\text { Participants' Name } \\
\text { (not real) }\end{array}$ & Gender & Year Level & Institute \\
\hline Shelley & Female & $3^{\text {rd }}$ & IEd \\
Patty & Female & $2^{\text {nd }}$ & IMaGoCS \\
Ken & Male & $3^{\text {rd }}$ & IIT \\
Ian & Female & $3^{\text {rd }}$ & IIT \\
Marine & Male & $2^{\text {nd }}$ & IAAS \\
Argon & Male & $2^{\text {nd }}$ & IAAS \\
King & Female & $3^{\text {rd }}$ & IEd \\
Dodong & Male & $2^{\text {nd }}$ & IMaGoCS \\
Jin & Female & $2^{\text {nd }}$ & IMaGoCS \\
Scarlet & Male & $2^{\text {nd }}$ & IMaGoCS \\
Darling & Female & $3^{\text {rd }}$ & IEd \\
\hline
\end{tabular}

The themes were extracted from the 11 participants of this study. As such, all data are the participants' expression from their experiences in the Mathematics in the Modern World course. These data helped actualize the themes of the study in order to portray first-recorded experiences of the students in the said course.

As stated, the objectives of the study sought to identify the struggles, coping mechanisms, and insights of the college students in Mathematics in the Modern World course. The themes under these objectives are presented in Table 2. These themes are discussed in details.

Table 2. Themes Identified for each Objective

\begin{tabular}{cc}
\hline Objectives & Themes \\
\hline Struggles & $\begin{array}{c}\text { ineffective delivery of instruction, insufficient learning } \\
\text { support, independent learning struggles, problematic } \\
\text { class interaction } \\
\text { positive attitude towards learning, learning initiatives, use } \\
\text { of schemata, utilization of technology } \\
\text { practical application, relevance to the } 21^{\text {st }} \text { century }\end{array}$ \\
Insights &
\end{tabular}

1.4.2 Struggles of the College Students in Mathematics in the Modern World Course

\section{A. Ineffective Delivery of Instruction}

The first struggle of the college students in the course is the ineffective delivery of instruction. This means that the students experienced difficulties in the course on the things they cannot control, but is part of the overall journey in the course.

With the novelty of the course, students find some of the activities and contents of the course struggling. Shelley said:

... however because of its wide concepts... It's just that it was not inculcated in my mind that's why the lessons didn't stay longer within the two-week discussion. There are instances that numerous topics may be fused in one meeting, and it will just depend on the students if they had understood it. (Shelley)

Marine discussed difficulty in various mathematical skills needed for one topic of the course, which support Shelley's struggles. Marine said:

We have encountered an activity where we were given a problem and we will make $\mathrm{x}$ and $\mathrm{y}$-axis then 
we'll plot it, shade the graph, and compute afterwards. With regards this complex task, I do struggle a lot with that and I had such a hard time figuring out an answer. Plotting, solving, and analyzing skills are involved in one problem, with no time to process. (Marine)

There are also activities and assessment tasks which the students find it challenging. There are also struggles posed by the instructor based on how they facilitated the course assessments. Shelley and Dodong said:

There are quizzes which really gave us hard times, because the way the teacher taught us is through giving easy examples then proceeds to quiz when he notices that we can do it already. So, he gives difficult items to challenge us. That's why we feel that it's difficult . . (Shelley)

The exhibit activity for example sir. You need to undergo a long process to accomplish your task. (Dodong)

Their experiences in Mathematics in the Modern World course were made difficult because of how the contents of the course are structured. The study of Amirali and Halai (2010) supported the findings of this study that difficult tasks are usually structured in college Mathematics because lessons are organized based on the presentation in the textbooks; thus, forcing students to get familiar with complicated concepts and formulae, and perform from the challenging activities and assessment tasks.

Moreover, Khalid and Embong (2019) supported the result as they emphasized that teachers tend to drag lessons from the syllabus just to finish what is expected, which ended up compromising students' creativity and understanding. Mohd Rustam (2016) and Langoban (2020) also supported the findings of this study that the fast pacing of the lesson impedes students' learning progress in Mathematics.

The lack of acknowledgement of the social media presence in the classroom and the absence of clear regulations and provisions regarding its use (intellectual property protection, private life, etc.) led to a misuse and inefficiency of social media use by the students whenever these are incorporated by teachers in their class. This finding of Holotescu and Grosseck (2013) supports the result of the study.

\section{B. Insufficient Learning Support}

The second struggle of the college students in the course is the insufficient learning support. The core ideas under this theme pertains to the scarcity and instability of the school's and students' resources throughout the students' learning process.

The interviews exposed difficulties in dealing with limited books and, both hard and online. When asked about the availability of resources in the school, Patty and Ken found it struggling in looking for references in their respective classes. They said:

I have experienced such, sir. It is really hard to find references that are credible. Sometimes I look it up on Google but it's not enough, not all topics are catered. And sometimes in YouTube, yet we doubt its validity. (Patty)

Since it's a new math sir, we are still in the transitional stage, so of course there is. It is not easy to find because there are no enough resources in the library and online. (Ken)

Struggles not only focus on the references, but to technology as well based on the concerns they have raised. Technological supports, both in the school and their own resources, are not enough to maximize their viewed learning for the course. As a matter of fact, Argon and Darling said:

In my section, lots of students are left behind in MMW because they don't have gadgets and no access to the internet. (Argon)

For example, in every discussion you give it a calculator is a must specifically the scientific calculator but sometimes we don't need it. And for the assignments and the topics that you discuss, we use the internet to study and to further understand the lesson. (Darling)

Aside from the causes of struggles of the students mentioned above, classroom facilities were also viewed as one concern in the learning support. Jin expressed:

The only problem [in the classroom] is that it is very hot sir. It definitely affects especially I have sweaty hands and sometimes it is hard for me to write. (Jin)

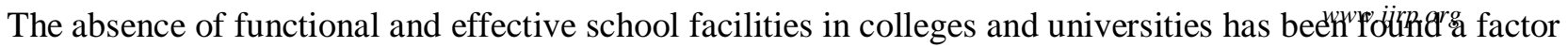
on unachieved goals and objectives of the system (Alimi, Ehinola, \& Alabi, 2012). In Davao Oriental State 
College of Science and Technology - Cateel Extension Campus, for example, it is view that classroom structures, such as proper ventilation, lighting, and location around the campus, negatively affects learning of the students when not managed carefully (Langoban, 2020).

These facilities, moreover, include lack of technological support, such as the accessibility of textbook resources and school facilities, the use of ICT-based teaching and learning aids, like the limited number of computer units, lacking skills in operating technological tools, and Internet connections. These findings of Tanang, Djajadi, Abu, and Mokhtar (2014) supported the findings of the study on how technological limitations of the school impacted learning in the Mathematics in the Modern World course.

Aside from technological problems, problems on the accessibility of references and books were also found out on some studies, supporting the result of this study. In Fiji, for example, rural schools are faced with outdated books and unavailability of updated editions (Lingam \& Lingam, 2013). Similarly, a school in Nigeria also expect scarcity of references that students could not even find books containing the topics they are looking for (Michael, 2015). In these reasons, students were identified as non-users of library books for Mathematics references (Capuno, Revalde, Etuban, Aventura, Medio, \& Demeterio, 2019).

\section{Independent Learning Struggles}

The third theme is the independent learning struggles of the college students in the course. Learners' difficulties and errors committed by themselves as they dealt with the course belong in this theme.

The interview revealed various struggles that the learners encountered. One thing that is highlighted in this their struggles in the time they exert in understanding the concepts and obtaining accurate answers in every problem. Argon said:

There was a lesson about one riddle - the Einstein riddle, about who owns the fish. You crash out cases. I think I was struggling with my time and effort. I missed an information about it. . . Time is really a struggle, especially to me who usually study only when there's a quiz. (Argon)

Aside from time that made it difficult in understanding the content, which results to struggles along the way, King and Dodong also emphasized the inability to analyze made it more challenging as well. They said:

The subject, Math is a solitary job that needs to be worked on alone because you need time to analyze the problem given to you. . . you really analyzing skills. Even before. It started developed when I encountered Math in the Modern World. (King)

... like the Language of Math, the first problem set of it. . It was hard for me to figure out how to get the answer. It's more on analysis. (Dodong)

Of all the struggles of the students, most of the participants expressed challenges they encountered in solving situational and real-world problems in the course. Scarlet and Jin said:

...like what I've said that its process was too many when we're solving. It feels like, later on you will not understand it anymore. Maybe because there was too much information. (Scarlet)

In Statistics Sir, before you get it done, you still need to undergo a long process to get the answer. And sometimes it gets confusing when I don't have a copy of the given formula. (Jin)

Students' struggles in Mathematics are also apparent to many colleges and universities around the world. For example, Gafoor and Karukkan (2015) supported the findings of the study as he pointed out that most students have difficulty in remembering mathematics formulae and equations, making them confused in solving mathematics problems. Also, Charles-Ogan and George (2015) supported that student even complain that despite the time they allot in trying to understand and learn mathematical contents and computational ways, they still struggle in getting a good performance.

On the other hand, Siniguian (2017) even showed similar findings of this study in Cagayan State University - Andrews Campus, Philippines. He found out that the BSEd Mathematics students showed that poor problemsolving skills and the inability to utilize correct mathematical concepts and methods affected their performances in the said discipline. Specifically, their difficulties come from recalling basic Mathematics facts, procedures, and formula, slow retrieval of facts and procedures, struggle in maintaining precision in mathematical works, and forgetting prior knowledge.

The students' struggle with the need to deal with time pressure in performing mathematical tasks, especially in the computation, as found by Caviola, Carey, Mammarella, and Szucs (2017), is also congruent to the findings of this study. In fact, it has been considered as a stressor to the students. San Jose, Seroma, 
Budomo, Adelantar, Tancinco, Arcangel, and Sedeno (2017) even pointed out that in San Mateo Municipal College in Rizal Province, Philippines, time pressure anxiety is seen to affect the students' performance in taking up the test in Mathematics.

\section{Problematic Class Interaction}

The fourth struggle faced by the college students in the course is the problematic class interaction. The items under this theme involved unhealthy social interactions and unfacilitated group works leading to challenging task accomplishment.

The interview discussed situations where mismanaged groups and immature decisions in the course. It started by having multiple ideas and conflicting attitudes in the class leading to struggles in interaction. King and Argon presented some details on this, as they said:

Maybe in the group activities because our ideas won't coincide when it comes to a certain problem. For example, the group activities, the activities that need to be time-bounded to beat submission, yet there are still conflicts despite an Amazing Race game is about to start. (King)

There are some in the classroom where there will be a student who has an attitude that will affect other students on their learning as if they cannot control their attitude then another student will get affected. (Argon)

Competition is also viewed to cause negative interactions, as King elaborated:

My classmates are very competitive. I need to double my time to catch up since it was very late [to make changes with the answers]... I can say that our classroom is very toxic. (King)

Another problem in class interaction is when groupmates won't work as what one expects them to be. This is mentioned by Jin in one of their group task, as she said:

Also in our exhibit was a bit struggling for us especially when it is time to meet the group, other classmates won't show up and will treat us coldly. (Jin)

Students' struggles with class interactions in Mathematics are observed in many studies as well. Mohd Rustam (2016) showed that peers contribute to the negative performance of the students, which supported the findings of this study. A study of Ganal and Guiab (2014) showed that college students of Philippine Normal University - North Luzon Campus used to display low interest and performance, and Mathematics anxiety because of problem interactions from their classmates.

Supports on the study's results were also found from Retnowati, Ayres, and Sweller (2017) explaining that misunderstandings in learning Mathematics surfaced because students do not need additional information in assisting them in their studies. Whereas, Popov, Biemans, Milder, Kuznetov, and Noroozi (2012) established that students' problems in group activities are sometimes caused by free-riding of other members in the group. Whenever some group members perceive that their efforts and ideas are not needed because of their groupmates, they usually withdraw from performing, making other members develop sense of injustice and unsupported efforts.

\subsubsection{Coping Mechanisms of the College Students in Mathematics in the Modern World Course}

\section{A. Positive Attitude Towards Learning}

The first theme on the coping mechanisms of the students in the course is having positive attitudes towards learning. This theme involves how learning utilized the good attitudes they embodied for Mathematics course, which eventually led them to a good performance.

The interviews revealed variety of attitudes and values that the participants had. At the start of the interview, several participants already established the need for hardwork and determination in the course, as it leads more values throughout.

... the will to learn is a must for every student. Determination to know and learn the lesson. (Ian)

It is not enough if you're hard-working, or what do you call that, . . . diligent. You should be responsible for anything. (Ken)

The values mentioned above won't be realized without actions. With that, important practive ijsp. sho observed in realizing these. Patty, Ken, Ian, and Darling mentioned various classroom practices that should be 
done in Mathematics in the Modern World course. As an exemplar, Patty said:

You're dedicated to understand the subject and the topics so you'll not have difficulties especially in finals. . And be attentive while the instructor is lecturing. When he discusses, the topic is already hard but if you will just depend on your own understanding, you can't clearly understand it. (Patty)

Darling and Marine also highlighted students to be open-minded. Marine discussed its importance, and the consequence of not having such, as he said:

Some students may see that math in the Modern World is hard but you need to be open-minded in understanding the topics because if you would understand the subject, you will learn from it. But if you're close-minded it will be difficult for you. (Marine)

Aside from having positive perceptions in understanding and learning concepts of the course, one should also practice confidence and self-esteem is sharing and communicating responses in assessment tasks. This was stressed by Shelley, as she said:

I can say that as a student, we all need confidence to answer in front especially it's Math. It is much better to have hands-on learning. And also, in solving, don't get nervous to stand in front and solve. It will help boost your confidence in a way and it's much easier to learn by doing that. (Shelley)

These findings were strongly supported by many studies expressing the effects of positive attitudes of students towards Mathematics learning in colleges and universities. Dagaylo-an and Tancino (2016), for example, found out that in Naval State University, Biliran Province, Philippines, improved students' achievement in their courses, including Mathematics, is correlated with their positive attitude towards learning, while those who exhibits unfavorable attitude often shows low performance.

Of the many tasks and experiences in a Mathematics class, certain attitudes, such as patience (Mohd, Mahmood, \& Ismail, 2011), diligence (Galla, Plummer, White, Meketon, D’Mello, \& Duckton, 2014), dedication (Kapur, 2018), self-confidence (Mazana, Suero Montego, \& Olifage, 2019; Van der Bergh, 2013; McCoach, 2011), self-esteem (Alva \& Manuel, 2017), and willingness (Curtis, 2006), pertaining how students allot their effort and time for the completion of their tasks have to be observed. Eventually, obtaining such positive attitudes towards in Mathematics classes likely improve students' achievement in the said discipline. These attitudes are also identified in the findings of this study, based on the participants' responses.

This study also identified the role of determination and perseverance in accomplishing mathematical tasks, in a short and a long run. Habibi (2018) supported the findings of this study that a class whose students are self-determined in learning Mathematics despite the variety of instructional strategies designed by the teacher, a significant difference of performance is observed, as compared to those classes which are not determined in Mathematics class. Moreover, when these tasks involved a long time to be done, Kutlu, Kartal, and Simsek (2017) also supported the result of the study that students should increase their perseverance in these situations in order to succeed.

\section{B. Learning Initiatives}

The second theme on the coping mechanisms of the students in the course is learning initiatives. Learning initiatives involve how the students utilized their established strategies in order to facilitate a smooth and effective journey for Mathematics course.

The interview exposed various learning initiatives of the participants, and how it helped them throughout the course. Time management, as mentioned by some of them, is one of the biggest considerations in this course. Darling, Shelley, Jin, and Ian expressed ideas on this, but Argon comprehensively discussed how time management in the course works, and its importance. He said:

Your time management is a must. If you don't manage your time in this course, it will be hard for you to pass. You should have more time to memorize those formulas and concepts and also don't practice procrastination. Because if you have a task then, if you describe Math in the Modern World, it is very time-consuming. So if you don't do it early then you will not finish the task given to you and other courses will get affected. (Argon)

Scarlet also emphasized what Argon said of how important it is to finish outputs as soon as you can. Scarlet said:

I don't like working when the deadline is fast approaching. When the instructor gives thaurs.sjignment, you'll do it right away so that you have a lot of time to study and to make it. (Scarlet) 
Ian even emphasized how allotting study time helped review concepts in the course, as she said:

In my study time, I study at a vacant time before math class starts. It's just a refresher to me, sir. (Ian)

Having time management is important, so as having notes to read as you spend time in the course. As a matter of fact, Shelley and Patty emphasized the importance of notes in reviewing. She said:

It's really necessary to take down notes so when you [do a] review, you'll realize and look back the discussion from your teacher. (Shelley)

When it comes to difficult topics, I always make sure to write it down, especially in this subject since there are many formulas to encounter and more on application. (Patty)

Exploring available resources are also seen as beneficial in learning and performing course activities and assessments.

The instructor will give the students' course outline and in the course outline, topics for the subject will be given so you should have it researched before you have your proper discussion so that you'll be familiar with the topic that will be discussed. (Scarlet)

When I receive the file, I scan the PowerPoint and I read it the night prior to the discussion so that I'll have shallow knowledge when it is being discussed. (Marine)

I'll look for problems that are related and I can also find it in the book. Sometimes the discussion and quiz are related to the problems that can be found in the book. And when a quiz comes, the problems are familiar with me because I've already looked on it. (Shelley)

Also, few responses also revealed that in the course, students preferred to study by themselves, with minimal group interaction. Dodong, King, Patty, Darling, and Argon discussed why this prefer such. Dodong, for example, said this:

For example, in solving, even if it is group work, if I do the solving [process] I like being alone. Although if I have a companion, I don't like being disturbed. (Dodong)

However, if things started to get difficult especially if they have bring-home tasks to work on, a considerable social interaction will help. Marine discussed how this helped, as he said:

... [one way is] comparing of answers with my classmates, because sometimes I miss some of my solutions and if we compare and contrast, you will immediately see where you got wrong. So for me, compare and contrast is good to check on where I miss out. (Marine)

One way of lessening confusion in the contents or obtaining wrong answers, as discussed by Marine, is asking questions to their classmates or even to the teacher. In fact, Patty, though a shy girl, appreciated this practice, as she said:

Because every subject has complex topics especially if we have forgotten the prior knowledge we have in math, so you should not hesitate to ask especially if you're doubtful and if you had misunderstood the lesson. You tend to ask yourself "why and where did I make mistakes in this one?" That's when I realized that if we exercise shyness, we won't achieve anything. (Patty)

In college Mathematics, students need to initiate learning activities to cope up from the demands of the discipline. With an aim to make learners think and approach Mathematics successfully in a broader context of life, Szabo, Kortesi, Guncaga, Szabo, and Neag (2020) discussed that students should practice specific methods for solving mathematical problems by exploring solving real-life challenges, which supported the findings of this study.

It is found that study habit is a moderating variable for the quantity of time spent in studying to the students' performance in the colleges such as students' time allocation in their studies (Nonis \& Hudson, 2010), and students' time allocation in their studies and lecture attendance is significantly related to their academic achievement (Ogundipe \& Falade, 2014). These results support the importance of time management of the students, as found in the study.

Moreover, Barry, Gay, Pelkey, Rothrock, and Mnayer (2019) concluded that printed textbooks with clear examples, answers with solutions, practice problems, explanations, definitions, and illustrations are useful instructional materials for studying, which supported the findings of the study. However, students can also opt to interact with their classmates through questions and discussions elicited from students' thinking, as it improves their clarity and precision in developing mathematical ideas (Foster, 2011). Meanwhilew, \$itkestiyarno and Dwidayati (2020) agreed in the result of this study as they emphasized that students who are working 
independently will them enhance their mathematical connections in their Mathematics subjects. To enhance their learning even more, Odiri (2015) valued the role a good learning environment with peaceful and supportive resources in realizing good students' performance.

\section{Use of Schemata}

The third theme on the coping mechanisms of the students in the course is the use of schemata. Using the schemata involves giving value of students' established learning through experiences and previous Mathematics classes for their future Mathematics journey.

The interviews showed how the participants used their schemata in the course, and its benefits. Darling, expressed how she realized the easier ways taught in Mathematics in the Modern World course because of her prior knowledge in high school She said:

When Math in the Modern World was introduced to us, there are familiar topics. So, I look it up in my senior high notebook and luckily, the formulas are still there. But in all honesty, Math in the Modern World is different because it feels like its formulas are different from the previous math $\mathrm{I}$ had, it was like an upgraded formula which I find easier than before. (Darling)

Moreover, prior knowledge will also help you in participating in the class, like what King said:

Maybe prior knowledge was a big help to me because whenever my teacher asks me questions, I can answer right away. (King)

Shelley has a more elaborative discussion of what King said, as she expressed:

. . . basic math knowledge is a big help because sometimes we have pre-tests. That time we also have oral recitations before we proceed to the topic itself. In that way, we can review somehow from the oral recitations. Usually, it's all about graphing and definitions. (Shelley)

Another significant thing to note is the use of learning which is gained from previous academic experiences and observation, which help facilitate assessment tasks in the course. This was discussed by Dodong, as he said:

I use different skills like when we were planning our exhibit. I watched videos and I've been doing that ever since. I like to watch life hacks in drawing. That's where I got the reference for our exhibit, I got it from the internet. So, as a student, you should have experience. Like before, I joined math quiz bee.

(Dodong)

One's previous mathematical knowledge and experience is an important factor in tertiary Mathematics. Various studies viewed to support the findings of the study on the importance of previous mathematical competence in tertiary Mathematics achievement. Anderton, Hine, and Joyce (2017), for example, found that competence in Mathematics for students at secondary school is significant in obtaining a higher first-year GPA. Similarly, Faulkner, Hannigan, and Fitzmaurice (2014) viewed that the attainment of students in the tertiary Mathematics are considered to be best predictor of third-level mathematics performance.

Moreover, the study of Lunsford and Poplin (2011) at Longwood University, Virginia State, USA, the importance of the acquired basic statistical skills, such as reading simple graphs and computing simple operations, is established. Indeed, those students with low scores on the 20-point basic skills test obtained a significantly low performance in the Statistics subject than those with high scores of the test. They eventually concluded the basic mathematical skills is a significant predictor for tertiary statistical courses. Moreover, the use of students' experiences and simulated real-life activities help students in their Mathematics performance, as posited by Pattison, Rubin, and Wright (2016). These results are also similar to these findings, which supports the study.

\section{Utilization of Technology}

The fourth theme on the coping mechanisms of the students in the course is the utilization of technology. This theme involves students' knowledge in using technology inside and outside the classroom to help them learn the contents in Mathematics course effectively and efficiently.

The interviews exhibited how useful for the participants to have knowledge in using numerous technological media, digital or non-digital, throughout the course. As most of the instructors provide slide presentations of their topic, the students also appreciated the use of phone to store and access the files anytime they can for their readings. Patty, for example, said: 
You have to know how to use smart phone because that is where I store files from PowerPoint that has math lessons especially the more important topics, and that is my means when studying. (Patty)

Shelley also emphasized the use of Internet in obtaining additional information, with some important concerns to observe. She said:

I can tell that Internet is a big help because you can look for further information about a topic. However, other resources are not reliable and credible. You doubt the given information because it contradicts the first one. I have read once from the Internet that's why after I research online, I make sure to verify it from the resources in the library. You really have to know how to use references. (Shelley)

Others, on the other hand, still emphasized the use of notebooks, aside from their gadgets, in learning the contents of the course. As Ken said:

[I really use supports like] my notebook since I am fond of writing down topics that I recall, especially the formulas, terms, and such. Those are very useful. (Darling)

King also added that highlighters, and calculator, as a mathematical tool, also helps her. She said:

I bring a calculator if it is needed but if not, a notebook will do because I like to jot down notes when it comes to math and I use highlighter pens to help me understand the lesson. You really have to prepare those things Sir. (King)

Lastly, books had also been an indispensable tool in the course. Jin and Scarlet emphasized this. As a matter of fact, Jin emphasized that books have been her main tool in the course, as she said:

I just [mainly] use books from the library Sir. (Jin)

The utilization of various technological strategies in the instructional processes were indeed found in the study. These technological strategies, which were classified by Bilbao, Dequilla, Rosano, and Boholano (2019) as traditional and digital, come in many forms in this study. Dundar (2016) expressed that contents of the notebooks of performing students showed remarkable effects towards them, as he posited that students should know how to enhance their note-taking methods at the start of the semester and schools should help students to improve this skill, through seminars, in order to increase their mathematical success. Cetin and Howard (2016), on the other hand, explained that the number of books borrowed by the students in the university library is positively correlated with their academic achievement.

The use of calculator, which is also found in this study, is supported by Ochanda and Indoshi (2011), as they discussed that students are actively involved in the mathematical process, allowing them to understand concepts, increase mastery of computing skills, and display of accurate answers. The use of mobile devices, such as cellphones and laptops, moreover, is found by Ariyanto, Kusumaningsih, and Aini (2018) to allow students to interact mathematical concepts in their everyday life in a meaningful manner, which also supported the results of this study. In fact, Fabian, Topping, and Barron (2016) posited that the growing role of mobile technology in the teaching-learning process allows students to bridge Mathematics class to the real-world scenarios.

\subsubsection{Insights of the College Students in Mathematics in the Modern World Course}

\section{A. Practical Application}

The first insight of the students in the course is its practical application. This theme includes items stating how the contents of the course are used to facilitate and mobilize daily transactions, and even innovate and design efficient and effective methods.

The interviews revealed that the participants saw applications of the course in many aspects of like. Argon, Patty, Ian, Marine, and Darling related these applications of the course in their own lives. As a matter of fact, what Argon liked about this course is its applications, as he discussed: 
What I like about Mathematics in the Modern World is it also engages outside in our classroom, like the application of its formula in nature, since we have topics like that. There is really an application.. (Argon)

Patty even highlighted some comparisons of the course to the previous Mathematics subject she encountered in her high school, as she said:

Math in the Modern world has application in real-life and its applications are evident meanwhile, the math subject before was very objective, sir. (Patty)

Argon also explained the same idea as Patty's, as he said:

I really like it specifically the application because in my high school days, it was more on discussion and examination. Unlike in the subject, Math in the Modern World where it has more activities and involving applications. (Argon)

Darling even applied her learning in the course in teaching her siblings about the application of the Mathematics in the Modern World course. She said:

For me sir, since the subject Mathematics in the Modern World, every topic and every discussion amaze us. When we are in our home we can somehow reflect especially when our siblings ask us questions about math and that is where I can apply the subject, in our home. (Darling)

Moreover, Jin realized the application of various concepts and formula in preparing for some assessment tasks, based on her experiences. She said:

For example, the topic Patterns that were first taught to us was very helpful in exams like PESO and even in the DNSC's entrance examination. (Jin)

For many times, the aim of having students see the application of Mathematics in the real-life situations has been observed by many countries around the world (Wong, et al., 2012) in order to help their performance of the said discipline. As such Carey, Hill, Devine, and Szücs (2017) posited that mathematical skills are essential not just for academic success, but also for efficient functioning in their everyday lives, which supported the findings of this study. Ahmad (2019) even emphasized all professions use Mathematics, may it be in a smaller portion of the task or a significantly large role in the field.

Many schools also utilized practical applications of Mathematics content in the instructional process. Beghetto (2016) and Yavuz Mumcu (2018) supported the findings of this study discussing that when learners are exposed to a variety of mathematical situations and opportunities through engaging and relevant problems, they will start to see its application in diversities of real life. Similarly, Dahiya (2014) posited that mathematical knowledge acquired through genuine mathematical problem-solving tasks and investigations enables students to use those for situations even if it's unfamiliar them, which help a person to live a meaningful and responsible life.

As students progress in their senior high school and tertiary mathematics, the value of relating the mathematical contents to practical applications is strengthened. The study of Arthur, Owusu, Asiedu-Adoo, and Arhin (2018) explained that the multi-disciplinarity of problems in mathematics will help students increase their interest in the discipline, especially of the connection is related to students' career preference, which supported the results of this study. Premadasa and Bhatia (2013) also supported this study that utilizing worded problems in various application areas helps students to relate problems in a specific field. Although it won't make students to really like Mathematics, but this will allow students to learn how to model problems and retain how these be applied in their future career, despite forgetting the details of algebraic formulae and procedures.

\section{B. Relevance to the $21^{\text {st }}$ Century}

The second theme on the insights of college students in the course is its relevance to the 21 st century. This theme involved core ideas that expressed how the contents of Mathematics in the Modern World course is seen in the modern environment and how it helped people of today upgrade traditional ways of thinking and living.

The interviews showed that the Mathematics in the Modern World course enhanced learning and environmental significance. When asked of how it helped her realize see the relevance of the course, King said: 
That is why it is called Mathematics in the Modern World since nowadays, technology is escalating and everything is instant. Therefore, Math has a big aspect of nurturing the modern world. (King)

Moreover, Ken supported what King said as he stated how the course helped him grow as a 21 st century learner, as he said:

... it helps you deal with real-life situations. Part of this is it conditions me to be ready and to be better at how to deal with life situations. And it's necessary to be logical as a 21 st-century learner. (Ken)

Ken even added how he preferred the course when further asked how he felt with the Mathematics in the Modern World course as compared to the previous mathematical courses he experienced in the high school. Ken further said:

I really don't like math. But at least in this one, I can see the advantages of Math in our real life. Like our everyday life or situation. (Ken)

Dodong also expressed the same observation. Darling also established how the course impacted her, as she said:

I think Mathematics in the Modern World is better since we are 21st-century learners and I find it relevant and important for myself. (Dodong)

Additionally, Patty expressed how happy she is in getting good grades of the subject because of how the content helped her perform well, as she said:

I was actually happy with the subject, honestly, that is the only subject where I got a high grade for the first semester because I really like the subject. It amazes me every time I solve math problems. Then this subject is not pure solving, it also has involvement in nature. (Patty)

Conclusively, Shelley discussed how it became ideal as a general education subject considering the scope of its contents. She said:

Because in MMW, it already captured or encompassed all the competencies needed to teach the basic knowledge in Mathematics, like the ways of solving in relation to the world. It's a great help compare to other Mathematics courses. (Shelley)

Making mathematical contents relevant to the 21 st century world is still new to Mathematics education, and sometime posits challenges in its realization. But with its promising effects, studies supporting its use started to grow. Based on the findings of Fadel (2014), which supported the results of this study, reasoning tools are viewed to help students in modern Mathematics, especially in improving the PISA scores of many countries by considering the PISA contexts: personal, societal, occupations, and scientific contexts, which teaches students to relate mathematical skills in their lives. Furthermore, the studies of Nicholas, et al. (2015), Joyce, et al. (2017), and Gradwohl and Eichler (2018) supported the study that knowledge in tertiary Mathematics will aid students in their future career in the various fields.

To realize these, schools started to conceptualize new strategies that will allow students to be more efficient and accurate in solving problems. As support the result of this study, Cahyono and Ludwig (2018), for example, found that students in the secondary and tertiary school in Semarang, Indonesia exhibited increase in engagement and achievement in Mathematics through letting students explore some outdoor activities using GPS-enabled mobile phone applications in solving mathematical problems. On the other hand, Szabo, et al. (2020) found that realizing mathematical procedures as teaching strategies, just like the Polya's problem solving methods, equipping students with new and essential knowledge to help them cope up from the rapidly changing environment posed by globalization, climate change, and technological disruption, and to allow them to link life situations into cross-curricular aspects in different subject areas.

Although studies are still scarce when it comes to activities allowing students to explore mathematical methods and concepts outside the classroom, Maciejewski (2017) suggested that teachers can start letting students experience solving non-mathematical tasks. When students work to obtain findings and solution to problems involving general planning tasks, they are somewhat utilizing, not just their mental structure of mathematical concepts, but also the episodic memories of these concepts, which were also done by the students in mathematics problem-solving tasks. This finding is congruent to the study in making student ready in dealing with life situations and in the involvement of natural processes. 
This study utilized the phenomenological qualitative research design. This study utilized the thematic analysis to determine the lived experiences of the college students for the said course. The data was gathered from the 11 participants of the Davao Del Norte State College, Panabo City, Davao Del Norte. An interview guide was created for the phone-call in-depth interview, and was presented to the evaluators for validity. The results identified that the struggles of the college students in the course are ineffective delivery of instruction, insufficient learning support, independent learning struggles, and problematic class interaction; their coping mechanisms are positive attitude towards learning, learning initiatives, use of schemata, and utilization of technology; and their insights on the course are its practical application and relevance to the $21^{\text {st }}$ century.

The study revealed that having positive attitude for Mathematics in the Modern World increases the preparation for the incoming students of course. Moreover, they will also likely be prepared if they do have the initiative in learning the course and they have background experiences and knowledge. Lastly, having an established knowledge in technological use improves their readiness for Mathematics in the Modern World course.

Based on these findings, incoming students in Mathematics in the Modern World should consider preparing themselves whenever they are about to enroll the course. To start with, they should allow new insights to foster within them about Mathematics, contrary to their previous negative perceptions in Mathematics, as the study found out that having positive attitude towards the subject is a good preparatory mechanism. Moreover, incoming students are recommended to strengthen their prior knowledge in Mathematics, design their own initiatives in learning the course, and their ability in using technology for Mathematics learning.

\section{References}

Abramovich, S., Grinshpan, A. Z., \& Milligan, D. L. (2019). Teaching mathematics through concept motivation and action learning. Education Research International, 2019. https://doi.org/10.1155/2019/3745406.

Adelson, J. L., \& McCoach, D. B. (2011). Development and psychometric properties of the math and me survey: Measuring third through sixth graders' attitudes toward mathematics. Measurement and Evaluation in Counselling and Development, 44(4), 225247. https://doi.org/10.1177/0748175611418522.

Ahmad, A. (2019). Applications of Mathematics in Everyday Life. https://www.researchgate.net/publication/332329700.

Alimi, O. S., Ehinola, G. B., \& Alabi, F. O. (2012). School Types, Facilities and Academic Performance of Students in Senior Secondary Schools in Ondo State, Nigeria. International Education Studies, 5(3), 44-48. http://dx.doi.org/10.5539/ies.v5n3p44

Alva, C., \& Manuel, L. (2017). Self-Esteem, Study Habits and Academic Performance among University Students. Journal of Educational Psychology-Propósitos Y Representaciones, 5(1), 101-127. http://dx.doi.org/10.20511/pyr2017.v5n1.145.

Amirali, M., \& Halai, A. (2010). Teachers' knowledge about the nature of mathematics: A survey of secondary school teachers in Karachi, Pakistan. Bulletin of Education and Research, 32(2), 45. https://ecommons.aku.edu/pakistan_ied_pdck/91.

Anderton, R. S., Hine, G., \& Joyce, C. (2017). Secondary school mathematics and science matter: Academic performance for the secondary student transitioning into university allied health and science courses. International Journal of Innovation in Science and Mathematics Education, 25(1), 34-47. https://openjournals.library.sydney.edu.au/index.php/CAL/article/view/11317.

Ariyanto, L., Kusumaningsih, W., \& Aini, A. N. (2018, March). Mobile phone application for mathematics learning. In Journal of Physics: Conference Series (Vol. 983, No. 1, p. 012106). IOP Publishing. http://dx.doi.org/10.1088/1742-6596/983/1/012106.

Arthur, Y. D., Owusu, E. K., Asiedu-Addo, S., \& Arhin, A. K. (2018). Connecting mathematics to real life problems: A teaching quality that improves students mathematics interest. IOSR Journal of Research and Method in Education (IOSR-JRME), 8(4), 65-71. doi: $10.9790 / 7388-0804026571$

Asikhia, O. A. (2010). Academic Procrastination in Mathematics: Causes, Dangers and Implications of Counselling for Effective Learning. International education studies, 3(3), 205-210. https://dx.doi.org/10.5539/ies.v3n3p205.

Barry, A. L., Gay, A. S., Pelkey, M. L., Rothrock, K., \& Mnayer, M. (2019). Students Tell Us the Best Way to Learn Mathematics in High School. Issues in the Undergraduate Mathematics Preparation of School Teachers, 2. https://files.eric.ed.gov/fulltext/EJ1223005.pdf.

Beghetto, R. A. (2016). Creative learning: A fresh look. Journal of Cognitive Education and Psychology, 15(1), 6-23. https://dx.doi.org/10.1891/1945-8959.15.1.6.

Bilbao, P., Dequilla, M. A. C., Rosano, D., \& Boholano, H. (2019). Technology for Teaching and Learning 1. LORIMAR PUBLISHING, INC. 776 Aurora Blvd., cor. Boston Street, Cubao, Quezon City, Metro Manila, Philippines.

Cahyono, A. N., \& Ludwig, M. (2018, March). Exploring mathematics outside the classroom with the help of GPS-enabled mobile phone application. In Journal of Physics: Conference Series (Vol. 983, No. 1, p. 012152). IOP Publishing. https://dx.doi.org/10.1088/1742-6596/983/1/012152.

Capuno, R., Revalde, H., Etcuban, J. O., Aventuna, M., Medio, G., \& Demeterio, R. A. (2019). Facilitating Learning Mathematics Through the Use of Instructional Media. International Electronic Journal of Mathematics Education, 14(3), 677-688. https://dx.doi.org/10.29333/iejme/5785.

Carey, E., Hill, F., Devine, A., \& Szücs, D. (2017). The modified abbreviated math anxiety scale: A valid and reliable instrument for use with children. Frontiers in psychology, 8, 11. https://dx.doi.org/10.3389/fpsyg.2017.00011.

Caviola, S., Carey, E., Mammarella, I. C., \& Szucs, D. (2017). Stress, time pressure, strategy selection and math anxiety in mathematics: A review of the literature. Frontiers in psychology, 8, 1488. https://dx.doi.org/10.3389/fpsyg.2017.01488.

Çetin, Y., \& Howard, V. (2016). An exploration of the relationship between undergraduate students' library book borrowing and academic achievement. Journal of Librarianship and Information Science, $48(4)$, ${ }^{\text {w }}{ }^{3}$ 382-388. https://doi.org/10.1177/0961000615572404. 
Charles-Ogan, G. L. A. D. Y. S., \& George, N. R. (2015). Investigating difficult concepts in senior secondary school mathematics curriculum as perceived by students. International Journal of Academic research and reflection, 3(6), 67-74. https://www.idpublications.org/wp-content/uploads/2015/07/.

CHEd Memorandum Order No. 20, s. 2013. "General Education Curriculum: Holistic Understandings, Intellectual and Civic Competencies". https://ched.gov.ph/cmo-20-s-2013/.

Creswell, J. W. (2012). Qualitative inquiry and research design: Choosing among five traditions. Sage Publishing House.

Creswell, J. W. (2013). Qualitative Inquiry and research design choosing among five approaches (3rd Ed). Thousand Oaks, CA: Sage Publications.

Curtis, K. M. (2006). Improving student attitudes: A study of a mathematics curriculum innovation (Doctoral dissertation, Kansas State University). https://core.ac.uk/download/pdf/5164247.pdf.

Dagaylo-an, M. B., \& Tancinco, N. P. (2016). Mathematics anxiety and the academic performance of the freshmen college students of the naval state university. Int. J. Eng. Sci. Res. Technol, 5, 1125-1136. https://dx.doi.org/10.5281/zenodo.58530.

Dahiya, V. (2014). Why Study Mathematics? Applications of Mathematics in Our Daily Life. http://www.ijiset.com/v1s10/IJISET_V1_I10_55.pdf.

Dündar, S. (2016). Does Writing Have Any Effect on Mathematics Success?. Journal of Education and Training Studies, 4(1), 1-10. https://doi.org/10.11114/jets.v4i1.989.

Education for All 2015 National Review Report, Philippines. UNESCO Digital Library. https://unesdoc.unesco.org/ark:/48223/pf0000230331.

Fabian, K., Topping, K. J., \& Barron, I. G. (2016). Mobile technology and mathematics: Effects on students' attitudes, engagement, and achievement. Journal of Computers in Education, 3(1), 77-104. https://dx.doi.org/10.1007/s40692-015-0048-8.

Fadel, C. (2014). Mathematics for the 21st Century: What Should Students Learn. Boston, Massachusetts: Center for Curriculum Redesign. https://curriculumredesign.org/wp-content/uploads/Maths-Methods-Tools-CCR.pdf.

Farooq, M. B., \& De Villiers, C. (2017). Telephonic qualitative research interviews: When to consider them and how to do them. Meditari Accountancy Research. http://dx.doi.org/10.1108/MEDAR-10-2016-0083.

Faulkner, F., Hannigan, A., \& Fitzmaurice, O. (2014). The role of prior mathematical experience in predicting mathematics performance in higher education. International Journal of Mathematical Education in Science and Technology, 45(5), 648-667. https://dx.doi.org/10.1080/0020739X.2013.868539.

Foster, C. (2011). Student-generated questions in mathematics teaching. The Mathematics Teacher, 105(1), $26-31$. https://dx.doi.org/10.5951/mathteacher.105.1.0026.

Gafoor, K. A., \& Kurukkan, A. (2015). Why High School Students Feel Mathematics Difficult? An Exploration of Affective Beliefs. Online Submission. https://dx.doi.org/10.13140/RG.2.2.18880.12800.

Galla, B. M., Plummer, B. D., White, R. E., Meketon, D., D’Mello, S. K., \& Duckworth, A. L. (2014). The Academic Diligence Task (ADT): Assessing Individual Differences in Effort on Tedious but Important Schoolwork. Contemp Educ Psychol, 39(4), 314-325. https://dx.doi.org/10.1016/j.cedpsych.2014.08.001.

Ganal, N. N., \& Guiab, M. R. (2014). Problems and difficulties encountered by students towards mastering learning competencies in mathematics. Researchers World, 5(4), 25. https://www.academia.edu/16269152/.

Gradwohl, J., \& Eichler, A. (2018, April). Predictors of performance in engineering mathematics. In INDRUM 2018. https://hal.archives-ouvertes.fr/hal-01849947/.

Habibi, M. (2018, September). Self-Determination in Mathematics Learning Process by Using Generative Multi-Representation Learning (GMRL) Model. In Journal of Physics Conference Series (Vol. 1097, No. 1, p. 012155). https://dx.doi.org/10.1088/1742$6596 / 1097 / 1 / 012155$.

Hodges, C. B., \& Kim, C. (2013). Improving college students' attitudes toward mathematics. TechTrends, 57(4), 59-66. doi:http://dx.doi.org/10.1007/s11528-013-0679-4.

Holotescu, C., \& Grosseck, G. (2013). An empirical analysis of the educational effects of social media in universities and colleges. Internet Learning, 2(1), 5. https://dx.doi.org/10.5682/2066-026X-12-027.

Joyce, C., Hine, G., \& Anderton, R. (2017). The association between secondary mathematics and first year university performance in health sciences. Issues in Educational Research, 27(4). http://www.iier.org.au/iier27/joyce.pdf

Kapur, R. (2018). Factors influencing the students academic performance in secondary schools in India. Factors Influencing the Student's Academic Performance in Secondary Schools in India, $1,25$. https://www.researchgate.net/publication/324819919_Factors_Influencing_the_Students_Academic_Performance_in_Secondary_ Schools_in_India.

Khalid, M., \& Embong, Z. (2019). Sources and possible causes of errors and misconceptions in operations of integers. International Electronic Journal of Mathematics Education, 15(2), em0568. https://dx.doi.org/10.29333/iejme/6265.

Kolb, D.A. (1984). Experiential Learning: Experience as a Source of Learning and Development. Upper Saddle River, NJ: Prentice-Hall, Inc.

Kusmaryono, I. (2014). THE IMPORTANCE OF MATHEMATICAL POWER IN MATHEMATICS LEARNING. International Conference on Mathematics, Science, and Education. https://www.researchgate.net/publication/303459705_THE_IMPORTANCE_OF_MATHEMATICAL_POWER_IN_MATHEMA TICS_LEARNING.

Kutlu, Ö., Kartal, S. K., \& Şimşek, N. T. (2017). Identifying the relationships between perseverance, openness to problem solving, and academic success in PISA 2012 Turkey. Eğitim Bilimleri Araştırmaları Dergisi, 7(1), 263-274. : http://dx.doi.org/10.22521/jesr.2017.71.9.

Lingam, G., and Lingam, N. (2013). Making learning and teaching a richer experience: a challenge for rural Fijian primary schools. Education Research Reviews, 8(21):2160-2168. https://dx.doi.org/10.5897/ERR2013.1622.

Lunsford, M. L., \& Poplin, P. (2011). From research to practice: Basic mathematics skills and success in introductory statistics. Journal of Statistics Education, 19(1). http://dx.doi.org/10.1080/10691898.2011.11889604.

Maciejewski, W. (2017). Mathematical knowledge as memories of mathematics. In Proceedings of the 41st Conference of the International Group for the Psychology of Mathematics Education (Vol. 3, pp pirp.org
http://mathwes.ca/MathematicalKnowledgeAsMemoriesOfMathematics.pdf. 
Mazana, Y. M., Suero Montero, C., \& Olifage, C. R. (2019). Investigating students' attitude towards learning mathematics. https://doi.org/10.29333/iejme/3997

Michael, I. (2015). Factors Leading to Poor Performance in Mathematics Discipline in Kibaha Secondary Schools (Doctoral dissertation, The Open University of Tanzania). https://core.ac.uk/download/pdf/44684738.pdf.

Mohd Rustam, M. R. (2016). Challenges in mathematics learning: a study from school students' perspective. Research on Educational Studies, Universiti Teknologi Malaysia, 1. https://www.researchgate.net/publication/321873178. [28] Langoban (2020)

Mohd, N., Mahmood, T. F. P. T., \& Ismail, M. N. (2011). Factors that influence students in mathematics achievement. International Journal of Academic Research, 3(3), 49-54. https://www.researchgate.net/profile/Mohd-Nazri-Ismail-2/publication/228757092.

Moustakas, C. (1994). Phenomenological research methods. Sage publications.

Nicholas, J., Poladian, L., Mack, J., \& Wilson, R. (2015). Mathematics preparation for university: entry, pathways and impact on performance in first year science and mathematics disciplines. International Journal of Innovation in Science and Mathematics Education, 23(1). https://openjournals.library.sydney.edu.au/index.php/CAL/article/view/8488.

Nitisha, M. (2018). Role of Mathematics Education in Sustainable Rural Development. International Journal for Research in Engineering Application \& Management (IJREAM), ISSN : 2454-9150 Special Issue - NSAPSDS - 2018. http://dx.doi.org/10.18231/24549150.2018.1162.

Nonis, S. A., \& Hudson, G. I. (2010). Performance of college students: Impact of study time and study habits. Journal of education for Business, 85(4), 229-238. https://dx.doi.org/10.1080/08832320903449550.

Ochanda, J. P., \& Indoshi, F. C. (2011). Challenges and benefits of using scientific calculators in the teaching and learning of Mathematics in secondary school education. Journal of Media and Communication Studies, 3(3), 102-111. https://repository.maseno.ac.ke/handle/123456789/1890.

Odiri, O. E. (2015). Relationship of Study Habits with Mathematics Achievement. Journal of Education and Practice, 6(10), 168-170. https://files.eric.ed.gov/fulltext/EJ1081665.pdf.

Ogundipe, M. A., \& Falade, O. A. (2014). Student-Teacher Perception of Time Allocation and Academic Achievement in Tai Solarin University of Education. International Journal of Learning and Development, 4(1), 65. https://dx.doi.org/0.5296/ijld.v4i1.5132.

Ojo, A. A. (2019). The impact of procrastination on students' academic performance in secondary schools. International Journal of Sociology and Anthropology Research, 5(1), 17-22. https://www.eajournals.org/wp-content/uploads/The-Impact-ofProcrastination-on-Students-Academic-Performance-in-Secondary-Schools.pdf.

Pagtalunan, T. (2019). Determinants of Students' Learning in Mathematics in the Modern World. SSRN: https://dx.doi.org/10.2139/ssrn.3432261.

Passarelli, A. M., \& Kolb, D. A. (2012). Using experiential learning theory to promote learner learning and development in programs of education abroad. Learner learning abroad: What our learners are learning, what they're not, and what we can do about it, 137 161. https://weatherhead.case.edu/departments/organizational-behavior/workingpapers/wp-11-03.pdf.

Pattison, S., Rubin, A., \& Wright, T. (2016). Mathematics in informal learning environments: a summary of the literature. https://www.informalscience.org/sites/default/files/InformalMathLitSummary_Updated_MinM_03-06-17.pdf.

Phillips-Pula, L., Strunk, J., \& Pickler, R. H. (2011). Understanding phenomenological approaches to data analysis. Journal of Pediatric Health Care. https://dx.doi.org/10.1016/j.pedhc.2010.09.004.

Popov, V., Brinkman, D., Biemans, H. J., Mulder, M., Kuznetsov, A., \& Noroozi, O. (2012). Multicultural student group work in higher education: An explorative case study on challenges as perceived by students. International Journal of Intercultural Relations, 36(2), 302-317. https://doi.org/10.1016/j.ijintrel.2011.09.004.

Premadasa, K., \& Bhatia, K. (2013). Real Life Applications in Mathematics: What Do Students Prefer?. International Journal for the Scholarship of Teaching and Learning, 7(2), n2. https://doi.org/10.20429/ijsotl.2013.070220.

Retnowati, E., Ayres, P., \& Sweller, J. (2017). Can collaborative learning improve the effectiveness of worked examples in learning mathematics?. Journal of educational psychology, 109(5), 666. http://dx.doi.org/10.1037/edu0000167.

Reyes, J. D. C. (2019). Mathematics Anxiety and Self-Efficacy: A Phenomenological Dimension. Journal of Humanities and Education Development (JHED), 1(1), 22-34. https://mail.theshillonga.com/index.php/jhed/article/view/9.

San Jose, P., Seroma, T., Budomo, A., Adelantar, B., Tancinco, R., Arcangel, F., \& Sedeno, S. (2017). THE EFFECTS OF TIME PRESSURE ON TAKING ABSTRACT REASONING TEST. https://www.academia.edu/33966196.

Schleicher, A. (2019). PISA $2018 \quad$ Insights and $\quad$ Interpretations. https://www.oecd.org/pisa/PISA\%202018\%20Insights\%20and\%20Interpretations\%20FINAL\%20PDF.pdf.

Schwab, K. \& Sala-i-Martin, X. (2016). The Global Competitiveness Report 2016-2017. World Economic Report, Geneva. http://www3.weforum.org/docs/GCR2016-2017/05FullReport/TheGlobalCompetitivenessReport2016-2017_FINAL.pdf.

Shenton, A. K. (2004). Strategies for ensuring trustworthiness in qualitative research projects. Education for information, 22(2), 63-75. http://dx.doi.org/10.3233/EFI-2004-22201.

Siniguian, M. T. (2017). Students difficulty in solving mathematical problems. International Journal of Advanced Research in $\begin{array}{llll}\text { Engineering } \quad \text { and } & \text { Sciences, } & 6(2), & 1-12 .\end{array}$ https://www.academia.edu/9066326/Students_Difficulty_in_Solving_Mathematical_Problems.

Smith, J. A., \& Osborn, M. (2008). Interpretive phenomenological analysis. In J. A. Smith (Ed.), Qualitative psychology: A practical guide to research method (pp. 53-80). Sage.

Sukestiyarno, Y. L., \& Dwidayati, N. K. (2020, June). The Influence of Independent Learning and Structure Sense Ability on Mathematics Connection in Abstract Algebra. In International Conference on Science and Education and Technology (ISET 2019) (pp. 57-64). Atlantis Press. https://doi.org/10.2991/assehr.k.200620.011.

Szabo, Z. K., Körtesi, P., Guncaga, J., Szabo, D., \& Neag, R. (2020). Examples of Problem-Solving Strategies in Mathematics Education Supporting the Sustainability of 21st-Century Skills. Sustainability, 12(23), 10113. https://doi.org/10.3390/su122310113.

Tanang, H., Djajadi, M., Abu, B., \& Mokhtar, M. (2014). Challenges for Teachers in Developing their Teaching Professionalism: A Case Study of Secondary School in Makassar, Indonesia. Journal of Education and Learning, 8(2), 132-143. https://dx.doi.org/10.11591/edulearn.v8i2.215.

Van der Bergh, E. (2013). The influence of academic self-confidence on mathematics achievement. Doctoral dissertation, North-West University. http://repository.nwu.ac.za/handle/10394/10180.

Wallace, A. D. (2018). The Path to Math: Analysis of Student Mathematical Stories. The Universily of of Risssissippi. https://egrove.olemiss.edu/hon_thesis/103. 
Wong, K. Y., Zhao, D., Cheang, W. K., Teo, K. M., Lee, P. Y., Yen, Y. P., ... \& So, H. J. (2012). Real-life mathematics tasks: A Singapore experience. http://hdl.handle.net/10497/11492.

Yavuz Mumcu, H. (2018). Examining Mathematics Department Students' Views on the Use of Mathematics in Daily Life. International Online Journal of Education and Teaching, 5(1), 61-80. https://files.eric.ed.gov/fulltext/ED603755.pdf. 